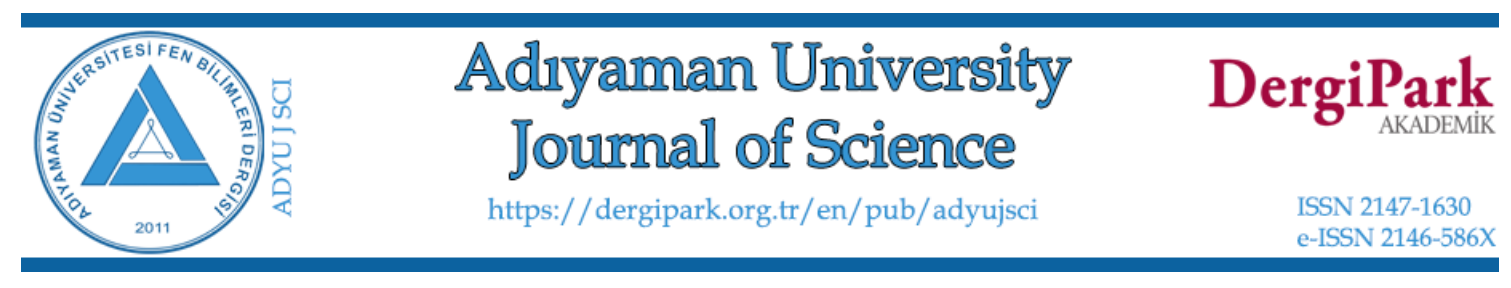

\title{
Response Surface Methodology Based Nickel Bioremoval by Penicillium citrinum Grown in Dilute Acid Pretreated Lignocellulosic Material
}

\author{
Ekin DEMIRAY ${ }^{1,2 *}$ \\ ${ }^{I}$ Adyaman University, Faculty of Science and Literature, Department of Biology, Adlyaman, Turkey \\ ${ }^{2}$ Ankara University, Science Faculty and Literature, Biology Department, Ankara, Turkey \\ edemiray@ankara.edu.tr,ORCID:0000-0003-2675-134X
}

\begin{tabular}{lll}
\hline Received: 29.12.2020 & Accepted: 09.05.2021 & Published: 30.06.2021
\end{tabular}

\begin{abstract}
The present study demonstrates the effectiveness of Ni (II) bioremoval by Penicillium citrinum fungus cultivated in carrot pomace medium. Experimental model for $\mathrm{Ni}$ (II) removal was developed using central composite design (CCD) based on response surface methodology (RSM). According to the model, the effects of some key parameters such as $\mathrm{pH}$, initial $\mathrm{Ni}$ (II) loading, and initial carrot pomace loading on Ni (II) bioremoval was found as significant $(p<0.05)$. The highest bioremoval was oberved as $82.01 \%$ in the presence of $\mathrm{pH} 5,50 \mathrm{mg} / \mathrm{L}$ initial $\mathrm{Ni}$ (II), and $100 \mathrm{~g} / \mathrm{L}$ initial biomass loadings, respectively. Results revelaed that the usage of Penicillium citrinum were proven to be effective in removing of $\mathrm{Ni}$ (II).
\end{abstract}

Keywords: Penicillium citrinum; Bioremoval; Response surface methodology. 


\section{Seyreltik Asit Ön-İşlemi ile Muamele Edilen Lignoselülozik Materyalde Geliştirilen Penicillium citrinum'un Yüzey Tepki Metodolojisi Temelli Nikel Biyogiderimi}

\section{$\ddot{O} \mathbf{z}$}

$\mathrm{Bu}$ çalışma, havuç posası içeren besiyerinde geliştirilen Penicillium citrinum fungusunun $\mathrm{Ni}$ (II) biyogiderimini etkin bir şekilde gerçekleştirdiğini göstermektedir. Çalışmada Ni (II) giderimi adına yanıt yüzey metodolojisine (RSM) dayalı merkezi bileşik tasarım (CCD) kullanılarak deneysel bir model geliştirilmiştir. Modele göre, başlangıç Ni (II) ve havuç posası konsantrasyonu ile $\mathrm{pH}$ gibi bazı önemli parametrelerin Ni (II) biyogiderimi üzerindeki etkileri anlamlı bulunmuştur ( $\mathrm{p}<0.05)$. En yüksek giderim $50 \mathrm{mg} / \mathrm{L} \mathrm{Ni}(\mathrm{II}), 100 \mathrm{~g} / \mathrm{L}$ biyokütle ve $\mathrm{pH} 5$ 'te \%82.01 olarak gözlenmiştir. Sonuçlar, Penicillium citrinum kullanımının Ni (II) 'nin gideriminde etkili olduğunu ortaya koymaktadır.

Anahtar Kelimeler: Penicillium citrinum; Biyogiderim; Tepki yüzey metodolojisi.

\section{Introduction}

As a result of industrialization, hazardous substances such as heavy metals cause serious problems for the environment, animals, and plants. These molecules can be harmful when the proper treatment methods are not performed [1]. The toxic effects of heavy metals are well known in the literature. They affect the brain, kidney, skin, or lung negatively, and they also have carcinogenic effects on certain organisms [2]. Therefore, different removal techniques such as physical, chemical, and biological are carried out for bioremoval of heavy metals from the wastewaters.

Although physicochemical methods can provide effective heavy metal removal, high capital costs and expensive regeneration processes limit their usage [3]. On the other hand, bioremoval is a cheap and effective alternative to the other techniques. Microorganisms produce high biomass yields; they have a fast growth rate and suitable for genetic manipulations [4]. For these reasons, different microorganisms such as fungi are used for textile dye or heavy metal removal from aquatic environments [5]. Penicillium citrinum is a widespread mesophilic fungus naturally found on different plants such as wheat or citrus species. Biotechnological applications of $P$. citrinum such as uranium (IV) biosorption [6], metabolite and enzyme production [7, 8], or textile dye removal [9] were shown in the literature previously.

Lignocellulosic biomass is one of the most abundant and underutilized raw materials on Earth. Cellulose and hemicellulose present in the lignocellulose contain fermentable sugars, which are very suitable for microbial growth. However, to obtain fermentable sugars from 
lignocellulose, efficient pretreatment techniques are required [10]. Carrot pomace is an essential by-product of the juice and food industries. Millions of tons of carrot pomace are generated each year. After carrot processing, $50 \%$ of the raw material remains as pomace and this pomace contains neutral sugars, carotenoids, macroelements, and minerals ( $\mathrm{N}, \mathrm{P}, \mathrm{K}, \mathrm{Mg}, \mathrm{Na}, \mathrm{Ca}, \mathrm{Cu}, \mathrm{Mn}$, $\mathrm{Fe}$ and $\mathrm{Zn}$ ) which are essential for microbial growth and metabolic activity. Furthermore, carrot pomace has high sugar and nutritional content, and it can also accumulate the free sugars in its vacuoles $[11,12]$. Therefore, numerous studies about the carrot pomace are carried out in the literature $[13,14]$.

Most of the biological optimization studies focus on the evaluation of one variable at a time. However, the combined effect of different variables is significant for optimization. Response Surface Methodology (RSM) allows identifying the interaction between controllable factors. RSM also defines the effects of different factors on the response alone or combined [15]. For these reasons, RSM studies have been used in many other areas such as biofuel production [16], dye biosorption [17], or heavy metal bioremoval [18].

The aim of the current study was to investigate the experimental model for Ni (II) bioremoval by P. citrinum. Within this context, effects of initial Ni (II) concentration, $\mathrm{pH}$ and initial biomass loading were optimized by response surface methodology. This is the first report about the Ni(II) bioremoval of $P$. citrinum cultivated in carrot pomace by RSM optimization.

\section{Materials and Methods}

\subsection{Raw materials and pretreatment}

Ground carrot pomace (approximately smaller than $0.2 \mathrm{~mm}$ particle size) was obtained from BELSO Co./Ankara and was dried in an oven at $70^{\circ} \mathrm{C}$ overnight. Dried carrot pomace was kept in screw cap bottles until pretreatment. Pretreatment was carried out in autoclave with $1 \%$ $\mathrm{H}_{2} \mathrm{SO}_{4}$ for 15 min at $121^{\circ} \mathrm{C}$. The slurry was filtered through Whatman No:1 paper and was used in bioremoval experiments. The sugar concentration of carrot pomace was also determined before and after the experiments.

\subsection{Microorganisms}

P. citrinum was obtained from Ankara University Culture Collection. The fungus was kept in Potato Dextrose Agar (PDA) at $+4{ }^{\circ} \mathrm{C}$ until experiments. 


\subsection{Culture conditions}

$250 \mathrm{~mL}$ Erlen-Meyer flasks working volume with $100 \mathrm{~mL}$ were used for the experiments. Agitation speed and temperature were set as $125 \mathrm{rpm}$. and $30^{\circ} \mathrm{C}$, respectively. Uninoculated flasks with different $\mathrm{pH}$, initial biomass nickel loadings were used as control. All experiments were performed triplicate.

\subsection{Bioremoval with RSM studies}

Design Expert Software ${ }^{\circledR} 12$ was used for RSM experiments. Central composite design (CCD) with three levels was used to evaluate the effects of three variables on $\mathrm{Ni}$ (II) bioremoval of $P$. citrinum. Total 17 runs were created for RSM. pH (3-7), initial nickel loading (50-150 $\mathrm{mg} / \mathrm{L})$, and initial biomass loading $(50-150 \mathrm{~g} / \mathrm{L})$ were selected as independent factors. The data obtained from experiments, was statistically evaluated using analysis of variance (ANOVA) at significance level of $\mathrm{p}<0.05$ by using Design Expert Software ${ }^{\circledR} 12$.

\subsection{Analytical methods}

$\mathrm{Ni}(\mathrm{II})$ removal was measured spectrophotometrically (Shimadzu) at $340 \mathrm{~nm}$. wavelength, according to Snell and Snell [19]. Total reducing sugar concentrations were measured according to the DNS method [20].

\section{Results}

\subsection{Composition of carrot pomace}

In the current study, carrot pomace was used for $\mathrm{Ni}$ (II) bioremoval of $P$. citrinum. Carrot pomace was pretreated with dilute acid $\left(1 \% \mathrm{H}_{2} \mathrm{SO}_{4} \mathrm{v} / \mathrm{v}\right)$. Reducing sugar concentrations of different carrot pomace loadings were examined. Results were shown in Fig. 1. It was observed that increasing biomass loadings resulted in increased sugar contents. The highest sugar was obtained from $150 \mathrm{~g} / \mathrm{L}$ carrot pomace as $52.72 \mathrm{~g} / \mathrm{L}$. Sugar concentrations reduced to $24.69 \mathrm{~g} / \mathrm{L}$ when $50 \mathrm{~g} / \mathrm{L}$ carrot pomace was used. Moreover, in $100 \mathrm{~g} / \mathrm{L}$ carrot pomace loading, $38.63 \mathrm{~g} / \mathrm{L}$ sugar was detected. 


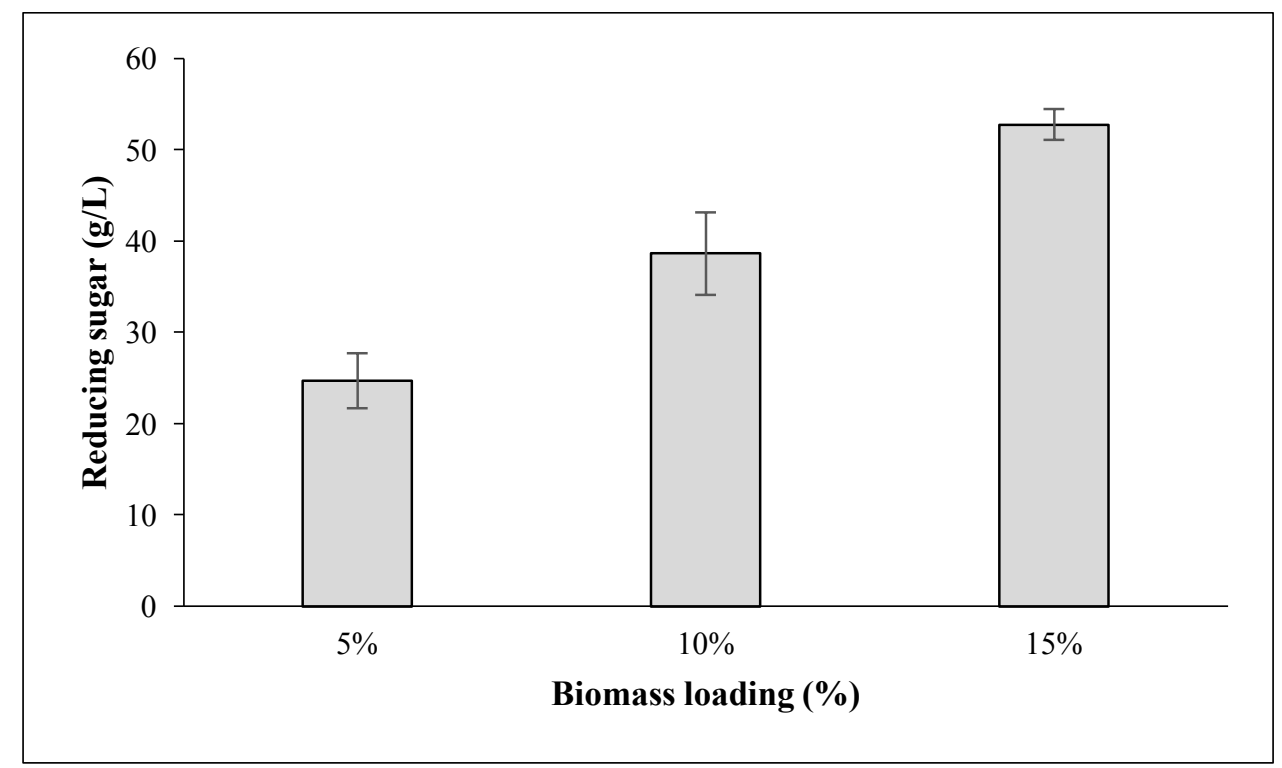

Figure 1: Reducing sugar concentrations of different carrot pomace loadings (Pretreatment: $1 \% \mathrm{H}_{2} \mathrm{SO}_{4}$ for $15 \mathrm{~min}$ at $121^{\circ} \mathrm{C}$ )

\subsection{Response Surface Methodology for Ni(II) Bioremoval}

In RSM experiments, central composite design was employed to investigate the effect of $\mathrm{pH}$, initial nickel, and biomass loadings. The descriptive table of the independent variables and bioremoval were shown as coded values in Table 1.

Table 1: Descriptive table of coded level for RSM analysis

\begin{tabular}{|c|c|c|c|c|c|}
\hline Factor & Name & Minimum & Maximum & Coded Low & Coded High \\
\hline $\mathbf{A}$ & $\mathbf{p H}$ & 3 & 7 & 3 & 7 \\
\hline $\mathbf{B}$ & $\begin{array}{c}\text { Initial nickel } \\
\text { concentration }\end{array}$ & 50 & 150 & 50 & 150 \\
\hline $\mathbf{C}$ & Biomass loading & 5 & 15 & 5 & 15 \\
\hline
\end{tabular}

The equation for the bioremoval yield was given in Eq (1). The final equation in terms of coded factors:

Eq (1): Bioremoval $=-231.79+102.33 * \mathrm{~A}+0.26 * \mathrm{~B}+2.48 * \mathrm{C}-0.028 * \mathrm{AB}+1.095 * \mathrm{AC}-$ $0.025 * \mathrm{BC}-10.39 * \mathrm{~A}^{2}+0.000030 * \mathrm{~B}^{2}-0.152 * \mathrm{C}^{2}$ 
where $\mathrm{A}, \mathrm{B}, \mathrm{C}$ are the coded values of $\mathrm{pH}$, initial nickel loading $(\mathrm{mg} / \mathrm{L})$, and biomass loading (\%), respectively.

The effects of different variables on bioremoval were shown in Table 2. Response surface graphs were also shown in Fig. 2 A, B, and C. The highest removal was found at the end of the $3^{\text {rd }}$ day of incubation. Therefore, RSM studies were carried out for the results of the $3^{\text {rd }}$ day of incubation.

Table 2: Effect of different variables on Ni(II) bioremoval of $P$. citrinum

\begin{tabular}{|c|c|c|c|c|c|}
\hline Std & Run & $\begin{array}{c}\text { Factor 1 } \\
\mathbf{A : ~} \mathbf{p H}\end{array}$ & $\begin{array}{c}\text { Factor 2 } \\
\text { B: Initial nickel } \\
\text { concentrations } \\
(\mathbf{m g} / \mathbf{L})\end{array}$ & $\begin{array}{c}\text { Factor 3 } \\
\text { C: Biomass } \\
\text { loading } \\
\mathbf{( \% )}\end{array}$ & $\begin{array}{c}\text { Response 1 } \\
\text { Bioremoval } \\
\mathbf{( \% )}\end{array}$ \\
\hline $\mathbf{4}$ & $\mathbf{1}$ & 7 & 150 & 5 & 20.71 \\
\hline $\mathbf{1 2}$ & $\mathbf{2}$ & 5 & 150 & 10 & 59.06 \\
\hline $\mathbf{1 0}$ & $\mathbf{3}$ & 7 & 100 & 5 & 40.43 \\
\hline $\mathbf{2}$ & $\mathbf{4}$ & 7 & 50 & 10 & 15.68 \\
\hline $\mathbf{6}$ & $\mathbf{5}$ & 7 & 50 & 10 & 81.72 \\
\hline $\mathbf{1 5}$ & $\mathbf{6}$ & 5 & 100 & 10 & 17.54 \\
\hline $\mathbf{9}$ & $\mathbf{7}$ & 3 & 100 & 10 & 82.01 \\
\hline $\mathbf{1 1}$ & $\mathbf{8}$ & 5 & 50 & 15 & 46.00 \\
\hline $\mathbf{8}$ & $\mathbf{9}$ & 7 & 150 & 5 & 14.08 \\
\hline $\mathbf{3}$ & $\mathbf{1 0}$ & 3 & 150 & 10 & 77.64 \\
\hline $\mathbf{1 6}$ & $\mathbf{1 1}$ & 5 & 100 & 15 & 19.82 \\
\hline $\mathbf{5}$ & $\mathbf{1 2}$ & 3 & 50 & 10 & 75.09 \\
\hline $\mathbf{1 7}$ & $\mathbf{1 3}$ & 5 & 100 & 5 & 53.87 \\
\hline $\mathbf{1 3}$ & $\mathbf{1 4}$ & 5 & 100 & 15 & 11.18 \\
\hline $\mathbf{7}$ & $\mathbf{1 5}$ & 3 & 150 & 5 & 13.22 \\
\hline $\mathbf{1}$ & $\mathbf{1 6}$ & 3 & 50 & 15 & 79.45 \\
\hline $\mathbf{1 4}$ & $\mathbf{1 7}$ & 5 & 100 & & \\
\hline
\end{tabular}

According to model $p$ values of the $\mathrm{pH}$, initial nickel and biomass loading were found as $0.0003,0.0155$, and 0.0004 , respectively, and $\mathrm{pH}$ was found as the most significant parameter and was followed by initial biomass loading. The highest Ni (II) removal was observed as $82.01 \%$ when $\mathrm{pH}$, initial nickel, and biomass loadings were adjusted as $5,50 \mathrm{mg} / \mathrm{L}$, and $100 \mathrm{~g} / \mathrm{L}$. Moreover, it was found that increasing Ni (II) concentrations caused lower removal yields. The lowest removal was $11.18 \%$ in $\mathrm{pH} 3,150 \mathrm{mg} / \mathrm{L}$ initial Ni (II) loading, and $150 \mathrm{~g} / \mathrm{L}$ biomass loading, respectively. According to the data in Fig. 2 A, B, and C, higher removal rates were observed in pH 5 and lower Ni (II) loadings. Furthermore, higher Ni (II) removal was observed from increased biomass loadings. 


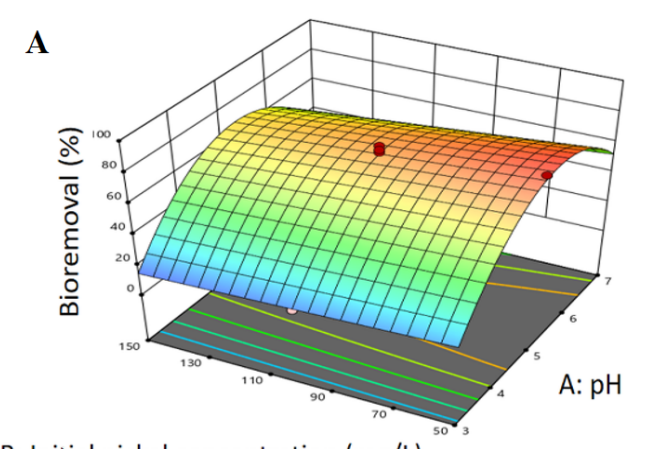

B: Initial nickel concentration ( $\mathrm{mg} / \mathrm{L}$ )
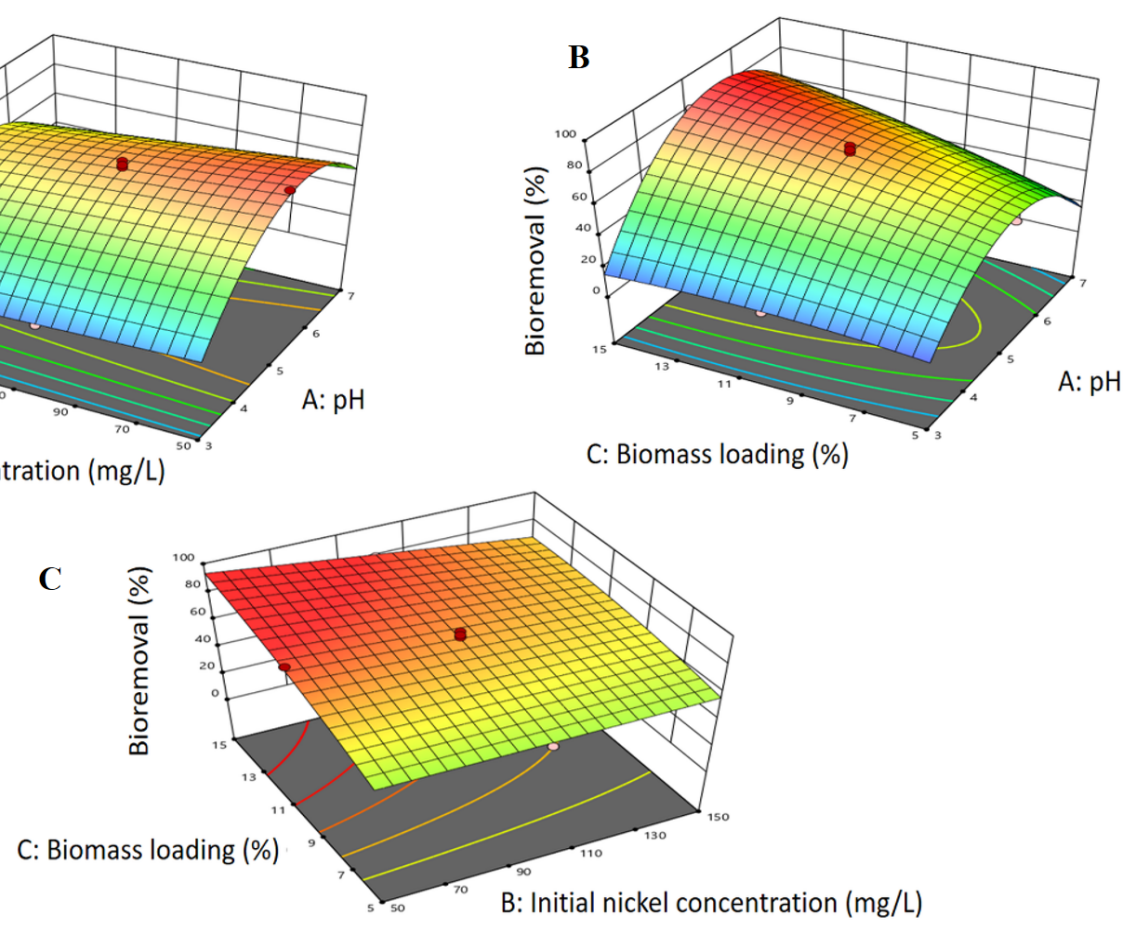

Figure 2: Response surface graphs of Ni bioremoval by $P$. citrinum in the presence of different conditions. A: Effect of $\mathrm{pH}$ and initial nickel concentration on bioremoval, B: Effect of $\mathrm{pH}$ and biomass loading on bioremoval, $\mathbf{C}$ : Effect of biomass loading and initial nickel concentration on bioremoval (Pretreatment: 1\% $\mathrm{H}_{2} \mathrm{SO}_{4}$ for $15 \mathrm{~min}$ at $121{ }^{\circ} \mathrm{C}$, incubation time 72 hours, agitation speed: $125 \mathrm{rpm}, \mathrm{T}: 30{ }^{\circ} \mathrm{C}$ )

Bioremoval of $\mathrm{Ni}$ (II) in the presence of $\mathrm{pH} 5,50 \mathrm{mg} / \mathrm{L}$ initial $\mathrm{Ni}$ (II), and $50 \mathrm{~g} / \mathrm{L}$ initial carrot pomace loadings were also given in Fig. 3. According to the figure, it was observed that $P$. citrinum consumed reducing sugars, and almost complete depletion occurred at the end of the 96 hours incubation period. Moreover, the highest removal was detected at the end of the 72 hours of incubation. After 72 hours, a slight decrease was found in the removal rates. Ni (II) removal was obtained as $22.84 \%, 72.69 \%, 82.01 \%$, and $71.76 \%$ at the end of the $24,48,72$, and 96 hours of incubation. 


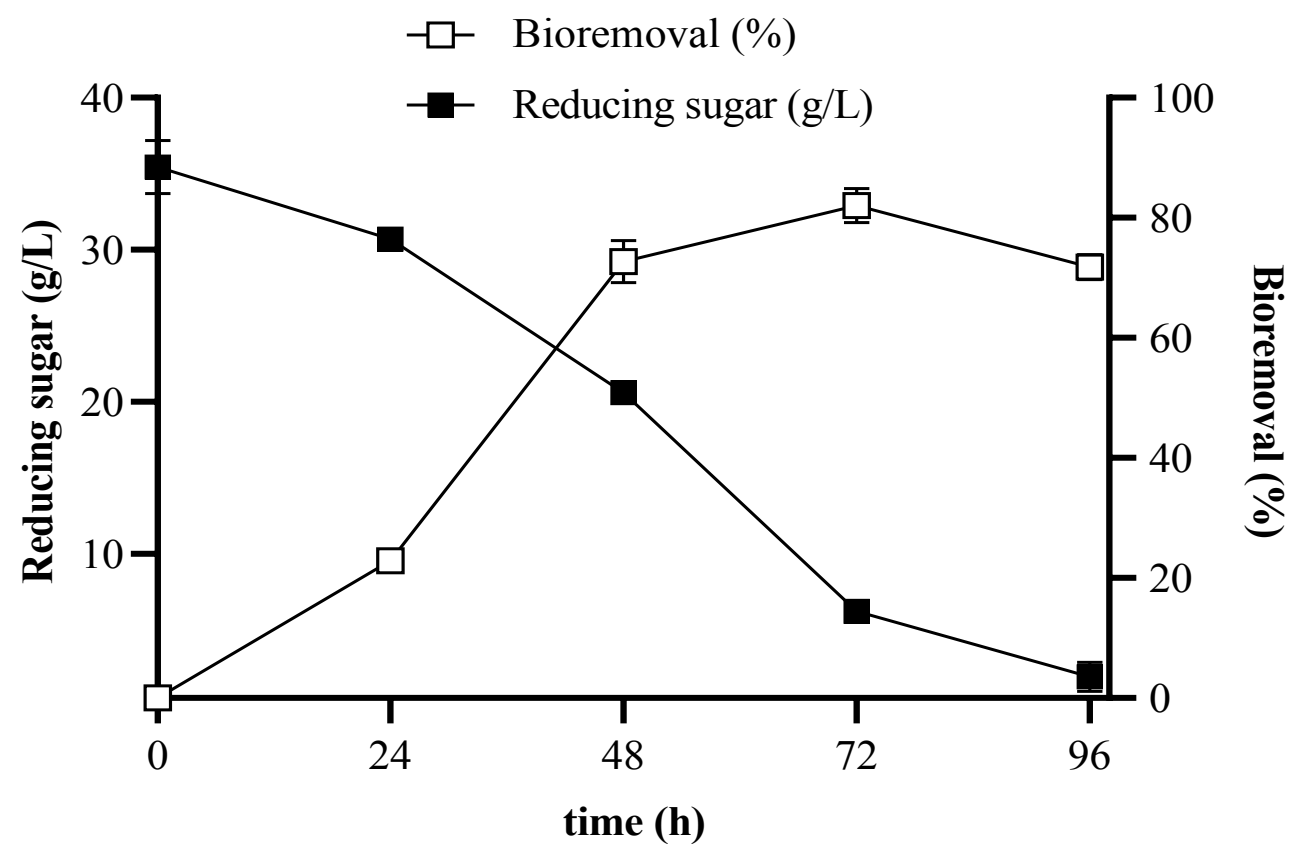

Figure 3: Time course of $\mathrm{Ni}$ (II) removal and reducing sugars during incubation of $P$. citrinum (Pretreatment: $1 \% \mathrm{H}_{2} \mathrm{SO}_{4}$ for $15 \mathrm{~min}$ at $121^{\circ} \mathrm{C}, \mathrm{pH}: 5$, initial $\mathrm{Ni}$ (II) concentration: $50 \mathrm{mg} / \mathrm{L}$, initial carrot pomace loading: $100 \mathrm{~g} / \mathrm{L}$, agitation speed: $125 \mathrm{rpm}, \mathrm{T}: 30^{\circ} \mathrm{C}$ )

\section{Discussion}

During acidic pretreatment, some inhibitory compounds derived from biomass such as phenolics, weak acids, or furan derivatives can be released into the medium. These molecules have a negative impact on microbial growth and metabolism [21]. Therefore, the concentration of reducing sugars from acid pretreated carrot pomace was determined. It was observed that increasing biomass loadings resulted in higher sugar. In the literature, similar reports showed that increased biomass loading caused higher sugar amounts. In a study about switchgrass, approximately $15 \mathrm{~g} / \mathrm{L}$ reducing sugar was observed in the presence of $50 \mathrm{~g} / \mathrm{L}$ initial biomass loading. This value increased around $45 \mathrm{~g} / \mathrm{L}$ when biomass loading was increased to $200 \mathrm{~g} / \mathrm{L}$ [22].

Despite the higher biomass loadings, such as $150 \mathrm{~g} / \mathrm{L}$, any lagging or inhibition was not observed in the growth of $P$. citrinum. This tolerance can be attributed to the inhibitor-resistant nature of P. citrinum cells. Similarly, Karpe et al. [23] reported that $P$. citrinum could virtually degrade hydrothermally pretreated grape wastes, which contained inhibitors such as 5-HMF. Furthermore, Tejas et al. [24] showed that $P$. citrinum could remove $70 \%$ phenolic substances from paper mill wastewaters with fungal fermentation. These results indicate that $P$. citrinum is a suitable microorganism for bioremoval studies. 
During RSM studies, it was indicated that $P$. citrinum effectively removed $\mathrm{Ni}$ (II) from carrot pomace medium, and $\mathrm{pH} 5$ was favorable for P. citrinum. Similarly, in one study, the highest $\mathrm{Cu}, \mathrm{Pb}$, and $\mathrm{Zn}$ removal rates of $P$. citrinum were observed in $\mathrm{pH} 6$ [25]. Medium $\mathrm{pH}$ is one of the most critical elements of metal uptake. In lower $\mathrm{pH}$ values, repulsive forces between the fungal cell surface and metal ions causedecreased metal binding to the surface. On the other hand, when $\mathrm{pH}$ increased, precipitation can occur, which may lead to reduction in bioremoval yields [26].

Moreover, lower bioremoval rates were observed when initial Ni(II) loading was increased (Figure 1a). This decline can be explained by the inhibitory effect of $\mathrm{Ni}(\mathrm{II})$. In the literature, it was previously shown that increased Ni(II) loadings led to lower bioremoval by Aspergillus versicolor [27]. Moreover, in a study about $\mathrm{Cu}(\mathrm{II})$ and $\mathrm{Ni}(\mathrm{II})$ bioremoval of Aspergillus sp., the highest removal in the presence of $50 \mathrm{mg} / \mathrm{L}$ initial $\mathrm{Ni}(\mathrm{II})$ was found as $86 \%$. On the other hand, when the initial $\mathrm{Ni}(\mathrm{II})$ loading increased to $100 \mathrm{mg} / \mathrm{L}$, bioremoval decreased to $78 \%$ [28].

Initial biomass loading is an essential parameter for microbial growth and bioremoval. Lower biomass loading can cause lower microbial growth. On the other hand, in higher biomass loading, inhibitory compounds can be released into the removal environment. Therefore, the effect of initial biomass loading on bioremoval was also investigated in the present study. According to Figure 1c, increased biomass loadings resulted in higher Ni(II) removal. In the literature, it was reported that higher sugar concentrations caused higher bioremoval rates. For instance, Kapdan and Kargi [29] found the decolorization of dyestuff by Coriolus versicolor as $54 \%$ in the presence of $5 \mathrm{mg} / \mathrm{L}$ glucose. Decolorization increased to $77 \%$ when the initial glucose loading was $10 \mathrm{mg} / \mathrm{L}$.

\section{Conclusions}

In the present study, response surface methodology was applied for $\mathrm{Ni}(\mathrm{II})$ removal by $P$. citrinum. Carrot pomace, which is a cheap and abundant by-product of food and juice industries, was used as a growth environment. Some critical parameters such as $\mathrm{pH}$, initial nickel loading, and initial biomass loading were optimized. P. citrinum effectively removed $\mathrm{Ni}$ (II) from carrot pomace medium. The highest bioremoval was observed as $82.01 \%$ in the presence of $50 \mathrm{mg} / \mathrm{L}$ $\mathrm{Ni}(\mathrm{II}), \mathrm{pH} 5$, and $100 \mathrm{~g} / \mathrm{L}$ initial carrot pomace loading. It was also detected that increased biomass loading resulted in higher removal rates, and removal rates decreased in the presence of increasing $\mathrm{Ni}(\mathrm{II})$ concentrations. This study reveals that the carrot pomace is a suitable raw material for the growth of microorganisms such as fungi, and P. citrinum is a promising bioagent for heavy metal removal. 


\section{Acknowledgement}

The author thankfull to Prof. Dr. Sevgi ERTUĞRUL KARATAY and Prof. Dr. Gönül DÖNMEZ for their valuable contributions to writing of the manuscript.

\section{References}

[1] Akbal, F., Camc1, S., Copper, chromium and nickel removal from metal plating wastewater by electrocoagulation, Desalination, 269(1-3), 214-222, 2011.

[2] Axtell, N.R., Sternberg, S.P., Claussen, K., Lead and nickel removal using Microspora and Lemna minor, Bioresource technology, 89(1), 41-48, 2003.

[3] Villaescusa, I., Fiol, N., Martínez, M., Miralles, N., Poch, J., Serarols, J., Removal of copper and nickel ions from aqueous solutions by grape stalks wastes, Water research, 38(4), 992-1002, 2004.

[4] Fu, F., Wang, Q., Removal of heavy metal ions from wastewaters: a review, Journal of environmental management, 92(3), 407-418, 2011.

[5] Agarwal, M., Singh, K., Heavy metal removal from wastewater using various adsorbents: a review, Journal of Water Reuse and Desalination, 7(4), 387-419, 2017.

[6] Pang, C., Liu, Y.H., Cao, X.H., Li, M., Huang, G. L., Hua, R., An, X.F., Biosorption of uranium (VI) from aqueous solution by dead fungal biomass of Penicillium citrinum, Chemical Engineering Journal, 170(1), 1-6, 2011.

[7] Tashiro, Y., Ueno, H., Takaba, M., Hayashi, S., Production of functional inulin-type fructooligosaccharides by an Enzyme from Penicillium citrinum, Current microbiology, 74(9), 1114-1117, 2017.

[8] Gu, Y., Ding, P., Liang, Z., Song, Y., Liu, Y., Chen, G., Li, J.L., Activated production of silent metabolites from marine-derived fungus Penicillium citrinum, Fitoterapia, 127, 207-211, 2018.

[9] Demiray, E., Assessment of apple and carrot pomaces for cost-effective reactive black 5 bioremoval by Penicillium citrinum, Journal of the Chilean Chemical Society, 65(3), 49144918, 2020.

[10] Paul, S., Dutta, A., Challenges and opportunities of lignocellulosic biomass for anaerobic digestion, Resources, Conservation and Recycling, 130, 164-174, 2018.

[11] Aimaretti, N.R., Ybalo, C.V., Rojas, M.L., Plou, F.J., Yori, J.C., Production of bioethanol from carrot discards, Bioresource technology, 123, 727-732, 2012.

[12] Surbhi, S., Verma, R.C., Deepak, R., Jain, H.K., Yadav, K.K. A review: Food, chemical composition and utilization of carrot (Daucus carota L.) pomace. International Journal of Chemical Studies, 6(3), 2921-2926, 2018.

[13] Singh, B., Panesar, P.S., Nanda, V., Utilization of carrot pomace for the preparation of a value added product, World Journal of Dairy \& Food Sciences, 1(1), 22-27, 2006. 
[14] Karatay, S.E., Dönmez, G., An economical phenol bioremoval method using Aspergillus versicolor and agricultural wastes as a carbon source, Ecological engineering, 73, 224-228, 2014.

[15] Yolmeh, M., Jafari, S.M., Applications of response surface methodology in the food industry processes, Food and Bioprocess Technology, 10(3), 413-433, 2017.

[16] Uyan, M., Alptekin, F.M., Cebi, D., Celiktas, M.S., Bioconversion of hazelnut shell using near critical water pretreatment for second generation biofuel production, Fuel, 273, 117641, 2020.

[17] Mona, S., Kaushik, A., Kaushik, C.P., Biosorption of reactive dye by waste biomass of Nostoc linckia, Ecological Engineering, 37(10), 1589-1594, 2011.

[18] Gönen, F., Aksu, Z., Single and binary dye and heavy metal bioaccumulation properties of Candida tropicalis: Use of response surface methodology (RSM) for the estimation of removal yields, Journal of hazardous materials, 172(2-3), 1512-1519, 2009.

[19] Snell, F.D., Snell, C.T., Colorimetric Methods of Analysis, third ed., vol. 2. D Van Nostrand Company, New York, 1959.

[20] Miller, G.L., Use of dinitrosalicylic acid reagent for determination of reducing sugar, Analytical chemistry, 31(3), 426-428, 1959.

[21] Palmqvist, E., Hahn-Hägerdal, B., Fermentation of lignocellulosic hydrolysates. II: inhibitors and mechanisms of inhibition, Bioresource technology, 74(1), 25-33, 2000.

[22] Ioelovich, M., Morag, E., Study of enzymatic hydrolysis of pretreated biomass at increased solids loading, Bioresources, 7(4), 4672-4682, 2012.

[23] Karpe, A.V., Harding, I.H., Palombo, E.A., Comparative degradation of hydrothermal pretreated winery grape wastes by various fungi, Industrial Crops and Products, 59, 228-233, 2014.

[24] Namboodiri, M.T., Pakshirajan, K., Sustainable and green approach of chitosan production from Penicillium citrinum biomass using industrial wastewater as a cheap substrate, Journal of environmental management, 240, 431-440.

[25] Bourzama, G., Rihani, A., Ennaghra, N., Ouled-Haddar, H., Soumati, B., Kinetic modeling for the biosorption of copper, lead and zinc by Penicillium citrinum isolated from polluted algerian beaches, Scientific Study Research. Chemistry Chemical Engineering, Biotechnology, Food Industry, 21(3), 321-332, 2020.

[26] Choudhary, S., Sar, P., Characterization of a metal resistant Pseudomonas sp. isolated from uranium mine for its potential in heavy metal (Ni2+, $\mathrm{Co} 2+, \mathrm{Cu} 2+$, and $\mathrm{Cd} 2+$ ) sequestration, Bioresource technology, 100(9), 2482-2492, 2009.

[27] Taştan, B.E., Ertuğrul, S., Dönmez, G., Effective bioremoval of reactive dye and heavy metals by Aspergillus versicolor, Bioresource technology, 101(3), 870-876, 2010.

[28] Pundir, R., Chary, G.H.V.C., Dastidar, M.G., Application of Taguchi method for optimizing the process parameters for the removal of copper and nickel by growing Aspergillus $s p$., Water resources and industry, 20, 83-92, 2018. 
Demiray (2021) ADYU J SCI, 11(1), 101-112

[29] Kapdan, I.K., Kargi, F., Biological decolorization of textile dyestuff containing wastewater by Coriolus versicolor in a rotating biological contactor, Enzyme and Microbial Technology, 30(2), 195-199, 2002. 